Weed Science 2017 65:61-72

(C) Weed Science Society of America, 2016

\title{
Predicting Yield Losses in Rice Mixed-Weed Species Infestations in California
}

\author{
Whitney B. Brim-DeForest, Kassim Al-Khatib, and Albert J Fischer*
}

\begin{abstract}
Although many pests constrain rice production, weeds are considered to be the major barrier to achieving optimal yields. A predictive model based on naturally occurring mixed-species infestations in the field would enable growers to target the specific weed group that is the greatest contributor to yield loss, but as of now no such models are available. In 2013 and 2014, two empirical hyperbolic models were tested using the relative cover at canopy closure of groups of weed species as independent variables: grasses, sedges, broadleaves, grasses and sedges combined, grasses and broadleaves combined, and all weed species combined. Models were calibrated using data from experiments conducted at the California Rice Experiment Station, in Biggs, CA, and validated across four sites over 2 years, for a total of 7 site-year combinations. Of the three major weed groups, grasses, sedges, and broadleaves, the only groups positively related to yield loss in the multispecies infestation were grasses. At the model calibration site, grasses and sedges combined best predicted yield loss (corrected Akaike information criterion [AICc] $=-21.5$ ) in 2013, and grasses alone best predicted yield loss (AICc $=-19.0$ ) in 2014. Across the validation sites, the model using grasses and sedges combined was the best predictor in 5 out of 7 site-years. Accuracy of the predicted values at the model validation sites ranged from $6 \%$ mean average error to $17 \%$ mean average error. No single model and set of parameters accurately predicted losses across all years and locations, but relative cover of grasses and sedges combined at canopy closure was the best estimate over the most sites and years.
\end{abstract}

Nomenclature: Rice, Oryza sativa L.

Key words: Ammannia spp., Cyperus difformis, ducksalad, Echinochloa spp., Heteranthera spp., hyperbolic models, late watergrass, Leptochloa fusca, modeling, redstem, ricefield bulrush, Schoenoplectus mucronatus, smallflower umbrella sedge, sprangletop, yield loss.

Rice in California is grown on approximately 200,000 ha around the Sacramento Valley in the center of the state. In 2009 rice production contributed approximately $\$ 997$ million to the gross domestic product in the state (Richardson and Outlaw 2010). Although many pests constrain rice production, weeds are considered the major barrier to achieving optimal yields worldwide (Zhang 1996). Weeds of rice in the southern United States may cause yield losses of up to $82 \%$ if uncontrolled, and recent research in California shows losses may reach $100 \%$ in dry-seeded systems (Brim-DeForest et al. 2017; Smith 1988). Amount of yield loss is weed species dependent, with certain weed species causing far less yield loss than others, even at high densities with season-long interference (Smith 1988). Studies in Arkansas showed rice yield losses

DOI: $10.1614 /$ WS-D-16-00079.1

*First, second, and third authors: Graduate Student, Professor, and Professor, Department of Plant Sciences, University of California, Davis, One Shields Avenue, Davis, CA 95616. Corresponding author's E-mail: kalkhatib@ucdavis.edu of up to $79 \%$ with season-long competition from barnyardgrass [Echinochloa crus-galli (L.) Beauv.] (Smith 1968). Losses in California rice due to seasonlong competition with late watergrass [Echinochloa phyllopogon (Stapff). Koss] were as high as $59 \%$ (Gibson et al. 2002). Losses were much lower with a broadleaf weed, ducksalad [Heteranthera limosa (Sw.) Willd.], which only caused losses of $21 \%$ when uncontrolled (Smith 1968).

One of the most pressing problems in the California rice agroecosystem is the development of herbicide resistance. The first herbicide-resistant weeds were identified in California rice in 1993 and were California arrowhead (Sagittaria montevidensis Cham. \& Schltdl.) and smallflower umbrella sedge (Cyperus difformis L.) (Pappas-Fader et al. 1993). Both were resistant to bensulfuron, an acetolactate synthase inhibitor (Pappas-Fader et al. 1993). Since then, eight other species have been identified, some with resistance to more than one mode of action (Heap 2016). Late watergrass biotypes have been identified that have non-target site based resistance mechanisms to five modes of action and are capable 
of detoxifying a wide array of unrelated herbicides (Fischer et al. 2000a, 2000b; Yasuor et al. 2008; Yun et al. 2005). Thus, for farmers, planning an effective herbicide program has become increasingly difficult, and in some cases, it may be necessary to decide which weed species or group to prioritize targeting to minimize yield loss. Currently, no information or model exists to assist growers with the decision.

Empirical models have been developed that can be used to predict yield losses in some crops, but many involve complex biological and ecological factors that make it difficult for farmers and crop advisers to use (Kwon et al. 1995; Wilkerson et al. 1991). The simplest of the models, the hyperbolic models, use only one measurement, such as plant density, relative leaf area, or relative cover, to predict losses (Cousens 1985; Kropff and Lotz 1993; Kropff and Spitters 1991; Kropff et al. 1995). Relative leaf area has been shown to be one of the best predictors of yield loss when evaluated under field conditions due to the fact that unlike plant density, it accounts for the relative competitive ability of the weeds (Ali et al. 2013). However, relative leaf area is difficult to measure in the field. Ngouajio et al. (1999a) found that relative leaf area correlated well with relative cover and that both predicted yield losses in corn equally well. Relative cover can be easily evaluated in the field by visual estimation. Since visual estimation may be subjective to the evaluator, photographic imaging is also an option (Lutman et al. 1996), and this may become even easier in the future with advancing digital capabilities. In a study of multispecies weed models used to predict yield losses in irrigated rice in Colombia (Florez et al. 1999), relative cover was the best predictor when compared with density, relative density, leaf area, relative leaf area, biomass, and relative biomass.

Most yield-loss models have been tested on a limited number of weed species at controlled densities of both crop and weed and have been parameterized for one weed species at a time. Some have incorporated multispecies weed competition, but only a few have been tested in rice (Florez et al. 1999; Swinton et al. 1994; Van Acker et al. 1997). In order to be useful in agricultural systems, models must be able to predict losses in natural situations and include multiple weed species (Ali et al. 2013).

Rice in California is primarily farmed in a continuously flooded irrigation system. Growers typically do not rotate crops, and thus the agroecosystem is characterized by just a few weed species: (1) grasses, which are watergrass species (Echinochloa spp.
P. Beauv.) and sprangletop [Leptochloa fusca (L.) Kunth]; (2) broadleaves, which are redstem (Ammannia L. spp.) and ducksalad (Heteranthera spp.); and (3) sedges, which are ricefield bulrush [Schoenoplectus mucronatus (L.) Palla] and smallflower umbrella sedge. Many growers and advisers in California have difficulty distinguishing between weed species in the field, particularly between different sedges or grasses, especially before weeds have reached maturity. Thus, the main goal of this research was to develop a simplified approach to estimating losses due to weed pressure, using groups of similar weed species instead of individual weed species as the independent variables. Specifically, the objectives were to: (1) compare two yield-loss models in rice based on relative cover assessments of natural weed communities at rice canopy closure; (2) assess which groups of weed species (grasses, sedges, broadleaves, or total combined) best predict yield loss in a mixed-species infestation; and (3) assess the predictive capability of the models over multiple sites and years.

\section{Materials and Methods}

\section{Site Characterization and Experimental Setup}

Model Calibration. Experiments for model calibration were conducted from 2013 to 2014 at the California Rice Experiment Station (CRES) in Biggs, CA $\left(39.46^{\circ} \mathrm{N}, 121.74^{\circ} \mathrm{W}\right)$. Soils are classified as Esquon-Neerdobe (fine, smectitic, thermic Xeric Epiaquerts and Duraquerts). Soil characteristics in the 0 to $15 \mathrm{~cm}$ profile are: $\mathrm{pH}$ of 5.1 , electrical conductivity (EC) of $0.35 \mathrm{dS} \mathrm{m} \mathrm{m}^{-1}$, and cation exchange capacity (CEC) of $32.6 \mathrm{cmol} \mathrm{kg}$. Organic matter (OM) is $2.8 \%$. The composition of sand, silt, and clay is 28,27 , and $46 \%$, respectively. Average winter rainfall (October to May) in Butte County (Durham Station) in 2012 to 2014 was $388 \pm 38 \mathrm{~mm}$ ( \pm SE) (California Irrigation Management Information System [CIMIS] 2016). The average minimum and maximum daily temperatures in Butte County during the growing season (May to October) in 2013 were $12.1 \mathrm{C}$ and $29.4 \mathrm{C}$, respectively. In 2014 they were slightly higher, with a minimum of $13.0 \mathrm{C}$ and a maximum of $31.7 \mathrm{C}$.

The experimental area was $1.8 \mathrm{ha}$, divided into nine main treatments plots of 0.2 ha each. Weedy and weed-free (herbicide-treated) areas were assigned to each plot, and the weed-free area was maintained by application of foliar herbicides. The weedy areas were 0.04 ha each. Three irrigation treatments were randomly assigned to the main plots in a randomized complete block design (RCBD). 
The irrigation systems were: (1) water-seeded control: conventional continuous flood irrigation, with the field flooded with approximately $10 \mathrm{~cm}$ of water at seeding and then drained 1 mo before harvest; (2) drill-seeded alternate wet and dry: dry seeded with irrigation flushes; (3) water-seeded alternate wet and dry: same as water-seeded control, with an early drain at canopy closure followed by two subsequent irrigation flushes (LaHue et al. 2016). Data from all irrigation systems were combined for this study for a total of nine pairs of weedy and weed-free plots per year.

All fields were seeded with "M-206" medium grain variety, and fertilizer was applied at recommended rates (Williams 2010). The water-seeded systems were planted at a seeding rate of $168 \mathrm{~kg} \mathrm{ha}^{-1}$. The drill-seeded system was seeded by drill at a rate of $112 \mathrm{~kg} \mathrm{ha}^{-1}$ into dry soil to a depth of $2 \mathrm{~cm}$.

At canopy closure of the rice, relative cover of weeds and rice (percentage of soil covered by each) was assessed in the weedy area of each plot by visual inspection of nine randomly placed quadrats of 25 by $25 \mathrm{~cm}$ (Hamill et al. 1977). Canopy closure of the rice was determined to be at $49 \mathrm{~d}$ after seeding (DAS) in 2013 and at 54 DAS in 2014. The percent relative cover at canopy closure of the following major weed species of rice was assessed per quadrat by four observers: watergrass species, smallflower umbrella sedge, sprangletop, ricefield bulrush, ducksalad, and redstem (Table 1). Due to the difficulty in distinguishing watergrass species before flowering, early watergrass [Echinochloa oryzoides (Ard.) Fritsch.], late watergrass, and barnyardgrass were all classified as watergrass (Echinochloa spp.). Species with less than $1 \%$ cover were eliminated from the assessment. The ratings for the nine quadrats and four observers were averaged per plot. Quadrats were rerandomized each year.

Rice was harvested at physiological maturity from two 3 by $6 \mathrm{~m}$ sections from both the weedy and herbicide-treated section in each plot using a smallplot combine, and rough rice yields were adjusted to $14 \%$ moisture. Yield losses for the weedy sections were calculated by dividing the weedy yield by the weed-free yield for each irrigation system.

Model Validation. The four sites for model validation (2013 and 2014) were in Glenn County, CA (GC), Yuba County, CA (YC), and two fields in Butte County, CA (BC1 and BC2) (Table 2). The distances from the model calibration site were approximately $36,45,3$, and $1 \mathrm{~km}$, respectively. The soils in Glenn County $\left(39.57^{\circ} \mathrm{N}, 122.07^{\circ} \mathrm{W}\right)$ are classified as Castro (fine, thermic Typic Calciaquolls). Soil characteristics in the 0 to $15 \mathrm{~cm}$ profile are: $\mathrm{pH} 7.9-8.2, \mathrm{EC}$ of 2.0 to $12.0 \mathrm{dS} \mathrm{m} \mathrm{m}^{-1}$, and CEC of $40.0 \mathrm{cmol} \mathrm{kg}^{-1}$. OM is $3.0 \%$. The composition of sand, silt, and clay is 22, 28, and $50 \%$, respectively. The soils in Yuba County, CA $\left(39.11^{\circ} \mathrm{N}\right.$, $121.52^{\circ} \mathrm{W}$ ) are characterized as San Joaquin (fine, mixed, active, thermic abruptic Durixeralfs). Soil characteristics in the 0 to $15 \mathrm{~cm}$ profile are: $\mathrm{pH}$ of $6.1, \mathrm{EC}$ of $0.0 \mathrm{dS} \mathrm{m} \mathrm{m}^{-1}$, and CEC of $15.0 \mathrm{cmol}$ $\mathrm{kg}^{-1}$. OM is $0.75 \%$. The composition of sand, silt, and clay is 42,38 , and $20 \%$, respectively. The two additional fields at the CRES had soil classified as Esquon-Neerdobe. Soil characteristics in the 0 to $15 \mathrm{~cm}$ profile of the two sites are the same: $\mathrm{pH}$ of 4.7, EC of $0.2 \mathrm{dS} \mathrm{m}^{-1}$, and CEC of $29.2 \mathrm{cmol} \mathrm{kg}^{-1}$. $\mathrm{OM}$ is $2.11 \%$. The composition of sand, silt, and clay is 20,33, and 47\%, respectively (Natural Resources Conservation Service, U.S. Department of Agriculture 2016).

Average winter rainfall (October to May) in Butte County for the BC1 and BC2 sites during the 2012 to 2014 period were the same those at the CRES. Average winter rainfall at the $\mathrm{YC}$ site in Yuba County in 2012 to 2014 was $465 \pm 57 \mathrm{~mm}$ ( \pm SE) (Browns Valley Station) (CIMIS 2016). The average minimum and maximum daily temperatures in Butte County (BC1 and BC2 sites) were the same as the temperatures at the CRES experimental site. In Yuba County (YC site) the 2014 growing season temperatures had a minimum of $14.3 \mathrm{C}$ of and a maximum of $29.6 \mathrm{C}$. Temperature and rainfall data were not available for Glenn County.

Sites selected for model validation were maintained by the University of California, Davis, for herbicide testing. Untreated controls (no herbicide applied) at these sites were used for model validation. The highest-yielding herbicide-treated plots were used as the weed-free yield comparison in each experiment. Plot areas for weed cover assessment and rice harvest were 3 by $6 \mathrm{~m}$. Experiments at each site were laid out as a RCBD with four replications. The total number of weedy plots varied at each site (Table 2). All sites were seeded with California medium-grain varieties, but the exact variety varied by location. Fields were irrigated using typical methods in California: (1) flood: field was flooded with approximately $10 \mathrm{~cm}$ of water, which was maintained until $1 \mathrm{mo}$ before harvest, when it was drained; (2) pinpoint: the same as the flood irrigation system, but with 4 to $7 \mathrm{~d}$ of drainage at approximately the 3- to 4-leaf stage of rice; (3) leathers: the same as the flood 
irrigation system, with 4 to $7 \mathrm{~d}$ of drainage right after seeding to allow the rice radicle to penetrate the soil; (4) drill: field is flush irrigated when dry and up to the 3- to 4-leaf stage of rice, when the field is flooded to $10 \mathrm{~cm}$ and then drained at 1 mo before harvest. In order to validate the model to predict yield loss over all rice systems in California, the data from all irrigation systems were combined for each site.

All fields were seeded at a rate of $134 \mathrm{~kg} \mathrm{ha}^{-1}$, except for the site in Yuba County, which was seeded at a rate of $202 \mathrm{~kg} \mathrm{ha}^{-1}$ due to soil type. Seeding rates were lower than recommended seeding rates to allow for weed growth. The flood, pinpoint, and leathers treatments were broadcast seeded, and the drill treatments were seeded by drill to a depth of approximately $2 \mathrm{~cm}$.

At each site, visual assessments were conducted of relative cover for each weed species and rice for each 3 by $6 \mathrm{~m}$ plot (Hamill et al. 1977) at 40 DAS. Evaluation timing was selected based on the critical period of competition for watergrass in rice, which is 30 DAS (Gibson et al. 2002). The difference in assessment timing from the calibration site was due to efforts to standardize the assessment timing for ease of use by growers. Four individual visual assessments were taken of each plot, and averages were used to calculate relative cover. Weed species assessed were as described in "Model Calibration."

Rice was harvested at physiological maturity from both the weedy and herbicide-treated plots in each field, and rough rice yields were adjusted to $14 \%$ moisture. The highest-yielding plot per irrigation system was used as the weed-free yield for the corresponding weedy yields from the same irrigation system.

\section{Statistical Analysis}

Model Calibration. Two nonlinear models were fitted to the data, using relative cover (RC) as the independent variable and rice yield loss as the dependent variable. Yield loss (YL) was calculated as follows (Equation 1):

$$
\mathrm{YL}=\frac{Y_{\mathrm{wf}}-Y_{\mathrm{w}}}{Y_{\mathrm{wf}}}
$$

where $Y_{\text {wf }}$ is the weed-free yield and $Y_{\mathrm{w}}$ is the weedy yield. Yield loss was calculated for nine pairs of plots each year at the CRES site. The number of pairs of plots at each validation site is listed in Table 2 .

For each species, RC was calculated by dividing the visual assessment of leaf area for the weed species by the weed plus rice leaf area. The assessment and calculations were done per quadrat for the CRES model calibration site and per plot at the model validation sites (Equation 2) (Ngouajio et al. 1999a, 1999b, 1999c):

$$
\mathrm{RC}=\frac{\mathrm{WRC}}{\mathrm{WRC}+\mathrm{CRC}}
$$

where WRC is the weedy leaf area and CRC is the crop leaf area. Mixed-species groups (grasses, sedges, broadleaves, and weeds combined) were summed per quadrat. The sum of the RC of sprangletop and watergrass species was RC grasses; the sum of the $\mathrm{RC}$ of ricefield bulrush and smallflower umbrella sedge was RC sedges; and the sum of the RC of ducksalad and redstem was RC broadleaves. The RC of weeds combined was the sum of RC grasses, sedges, and broadleaves.

Two empirical models were used to test the relationship between RC and YL. The first (Model 1) was proposed by Kropff and Spitters (1991) (Equation 3):

$$
\mathrm{YL}=\frac{q \mathrm{RC}}{1+(q-1) \mathrm{RC}}
$$

The coefficient $q$ is the relative damage coefficient, an estimate of the competitiveness between the crop and the weed. If $q<1$, the crop is more competitive; if $q>1$, the weed is more competitive. The second model (Model 2) is a modification of the first model, by Kropff and Lotz (1993) (Equation 4):

$$
\mathrm{YL}=\frac{q \mathrm{RC}}{1+[(q / m)-1] \mathrm{RC}}
$$

The estimated coefficient $m$ is maximum YL and adds an upper asymptote to Equation 3. The $q$ coefficient remains the same.

The data from CRES were fit to Model 1 (Equation 3) and Model 2 (Equation 4) using nonlinear regression in the curve-fitting module of SigmaPlot software (Jandel Scientific, San Rafael, $\mathrm{CA}$ ). Each weed group (grasses, sedges, and broadleaves) was fit separately. Models were run again with the following groups: grasses + sedges, grasses + broadleaves, sedges + broadleaves, and all weeds combined. Only those groups of species that showed a positive relationship with YL were modeled. To generate an additional set of parameters $(q$ and $m)$, the combined data from all sites $(\mathrm{GC}, \mathrm{BC} 1, \mathrm{BC} 2$, and $\mathrm{YC}$ ) were fit to Model 1 (Equation 3) and Model 2 (Equation 4), using nonlinear regression.

To evaluate whether the models from 2013 and 2014 could be combined into one data set or should be evaluated separately, the $F$-test was used 
(Chow 1960). The F-statistic was calculated using the following (Equation 5):

$$
F=\frac{S_{5 / k}}{S_{4}\left(n_{1}+n_{2}-2 k\right)}
$$

where $k$ is the number of parameters in the model, $n_{1}$ is the number of data points in the first model, and $n_{2}$ is the number of data points in the second model. A residual sum of squares was obtained by running a regression using the combined 2013 and 2014 data sets $\left(S_{1}\right) . S_{2}$ and $S_{3}$ were residual sums of squares calculated for the nonlinear regression for 2013 and 2014 separately: $S_{4}=S_{2}+S_{3}$ and $S_{5}=S_{4}-S_{1}$. When the computed $F$-value exceeded the critical $F$-value, the data from the two seasons could not be described using a single regression line, so regressions were calculated separately for the 2 yr (Table 3).

Model Validation. To evaluate the efficacy of one model over all sites, Models 1 and 2 with parameters generated from CRES were evaluated separately per site ( $\mathrm{GC}, \mathrm{BC} 1, \mathrm{BC} 2$, and $\mathrm{YC}$ ), using $\mathrm{RC}$ grasses, $\mathrm{RC}$ grasses and sedges, $\mathrm{RC}$ grasses and broadleaves, and $\mathrm{RC}$ weeds combined as independent variables. Evaluations of model fit were determined by calculating the root mean square error (RMSE) and mean average error (MAE) for each independent variable (Chai and Draxler 2014). The relative fits of the different models were compared using the Akaike information criterion corrected for small sample size (AICc) (Kniss et al. 2011; Spiess and Neumeyer 2010). AICc has been determined to be the most consistent means of comparing fit between models (Kniss et al. 2011; Spiess and Neumeyer 2010). An RMSE of 0 and MAE of 0 would indicate that the model fit perfectly. AICc is an absolute measure of model fit: the lower the number, the better the model performance.

\section{Results and Discussion}

Weed Population Composition. There was variation between sites in terms of which species' group (grasses, sedges, or broadleaves) comprised the majority of relative cover at canopy closure. The differences can best be attributed to the differences in the weed seedbank at each site. Differences in temperature as well as management decisions over the season may also contribute to differences both between sites and at each site over the $2 \mathrm{yr}$. At the CRES, the proportions of grasses, sedge and broadleaves varied over the $2 \mathrm{yr}$ (Table 1). In 2013 broadleaves (primarily ducksalad) were the largest group, and in 2014 grasses (primarily watergrass species) were the largest. Broadleaf RC decreased from 2013 to 2014, whereas grass and sedge RC both increased. The total RC of all weeds combined decreased from 2013 to 2014, but YL increased. The population composition across validation sites varied, depending on location. Glenn County (GC) had a high RC of sedges, both in 2013 and 2014 (Table 2). Grass RC increased over the $2 \mathrm{yr}$, as did sedge and broadleaf RC. The total RC of all combined weeds increased from 2013 to 2014, and YL decreased. The site in GC was least like the other sites in terms of weed composition, due to its high sedge population (more than 50\%). For Butte County $1(\mathrm{BC} 1)$, grasses were the largest proportion of RC in 2013 and 2014. RC of all weeds combined increased from 2013 to 2014, but YL declined. This corresponded to an increase in $\mathrm{RC}$ of sedges and broadleaves but a decrease in RC of grasses. At Butte County 2 (BC2), grasses had the greatest RC in 2013, whereas broadleaves had the greatest RC in 2014. Yuba County (YC) had the highest RC grass percentage of all sites surveyed, over both years, with more than half of the $\mathrm{RC}$ occupied by grass species. Combined weed cover was similar to the weed cover at other sites.

\section{Model Calibration}

Model 1 and Model 2 Comparison. Data for 2013 and 2014 could not be combined into one data set, due to significant differences in the nonlinear regressions for both Model 1 and Model 2 (Table 3), so both models were evaluated separately each year for the two data sets (CRES; GC, BC1, BC2, and YC combined). Model 1 and Model 2 are similar in that both use a simple measurement, weed RC, to predict YL. The value of parameter $q$ indicates the relative competitive ability of the weed vs. the crop at a given point in time (Kropff and Spitters 1991). A $q$-value greater than 1 indicates that the weed is outcompeting the crop, whereas a value less than 1 indicates that the crop is more competitive. Model 1 assumes maximum YL to be $100 \%$, whereas Model 2 contains the addition of an upper asymptote $(m)$ for maximum YL. The addition of the upper asymptote increases model fit in cropping systems in which YL is less than $100 \%$.

For data generated at the CRES, Model 1 was the better fit, both in 2013 and 2014, when comparing AICc values (Table 4). This can be attributed to the fact that the observed maximum YL in both years was $100 \%$, so adding an upper asymptote $(m)$ did 
Table 1. Relative cover at canopy closure of major weed species of rice and yield loss at harvest in model calibration plots at the CRES in Biggs, CA, in 2013 and 2014.

\begin{tabular}{lcc}
\hline & & Relative cover $^{\mathrm{a}}$ \\
\cline { 2 - 3 } Weed species & 2013 & 2014 \\
\hline Watergrass species [Echinochloa P. Beauv.] & & $\%$ \\
Sprangletop [Leptochloa fusca (L.) Kunth] & $30.7 \pm 12.9$ & $41.1 \pm 12.9$ \\
Ricefield bulrush [Schoenoplectus mucronatus (L.) Palla] & $5.5 \pm 3.5$ & $2.0 \pm 0.4$ \\
Smallflower umbrella sedge (Cyperus difformis L.) & $1.0 \pm 0.4$ & $2.6 \pm 0.9$ \\
Ducksalad [Heteranthera rotundifolia (Kunth) Griseb.] & $1.0 \pm 0.5$ & $2.3 \pm 0.8$ \\
Redstem (Ammannia L. spp.) & $47.3 \pm 12.2$ & $27.0 \pm 6.9$ \\
Grasses & $2.0 \pm 0.8$ & $0.1 \pm 0.1$ \\
Sedges & $36.2 \pm 15.1$ & $43.1 \pm 12.6$ \\
Broadleaves & $2.0 \pm 0.8$ & $5.2 \pm 1.6$ \\
Weeds combined & $49.4 \pm 12.6$ & $27.1 \pm 7.0$ \\
Yield loss & $87.7 \pm 3.2$ & $75.4 \pm 4.9$ \\
\hline
\end{tabular}

${ }^{a}$ Values are percent relative cover at rice canopy closure of nine plots (mean $\pm \mathrm{SE}$ ).

${ }^{\mathrm{b}}$ Values are percent yield loss in comparison to the weed-free yield (mean $\pm \mathrm{SE}$ ).

Table 2. Planting date, variety, irrigation system, weed composition, and yield reduction in rice planted at four sites in 2013 and 2014 : Glenn County (GC), Butte County 1 and 2 (BC1, BC2), and Yuba County (YC).

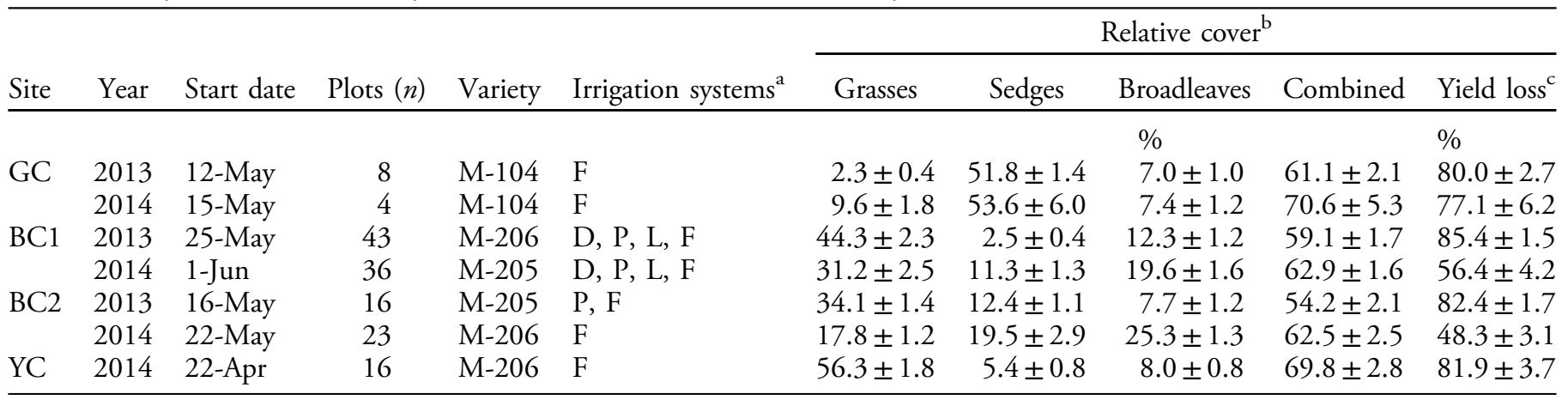

${ }^{\mathrm{a}} \mathrm{D}$, drill; F, flood; L, leathers; P, pinpoint.

${ }^{\mathrm{b}}$ Values are percent relative cover at rice canopy closure (mean $\pm \mathrm{SE}$ ).

${ }^{\mathrm{c}}$ Values are percent yield loss in comparison to the weed-free yield (mean $\pm \mathrm{SE}$ ).

Table 3. Comparison of nonlinear regressions of data generated at the CRES in Biggs, CA, using Model 1 and Model 2 fit for 2013 and 2014.

\begin{tabular}{|c|c|c|c|c|c|}
\hline Model & Species group ${ }^{a}$ & Season & $\mathrm{RSS}^{\mathrm{b}}$ & $\mathrm{df}_{\mathrm{den}}$ & $F^{c}$ \\
\hline \multirow[t]{4}{*}{1} & Grasses & 2013 vs. 2014 & 0.4156 & 16 & $17.7^{* * *}$ \\
\hline & Grasses + sedges & 2013 vs. 2014 & 0.3882 & 16 & $18.1^{* * *}$ \\
\hline & Grasses + broadleaves & 2013 vs. 2014 & 0.7462 & 16 & $11.7^{* *}$ \\
\hline & Weeds combined & 2013 vs. 2014 & 0.7388 & 16 & $9.1^{* *}$ \\
\hline \multirow[t]{4}{*}{2} & Grasses & 2013 vs. 2014 & 0.4040 & 14 & $8.0^{* *}$ \\
\hline & Grasses + sedges & 2013 vs. 2014 & 0.3821 & 14 & $7.9^{* *}$ \\
\hline & Grasses + broadleaves & 2013 vs. 2014 & 0.7402 & 14 & $6.2^{*}$ \\
\hline & Weeds combined & 2013 vs. 2014 & 0.7386 & 14 & $5.6^{*}$ \\
\hline
\end{tabular}

${ }^{a}$ Grasses: watergrass and sprangletop; grasses + sedges: watergrass, sprangletop, ricefield bulrush, and smallflower umbrella sedge; grasses + broadleaves: watergrass, sprangletop, ducksalad, and redstem; weeds combined: watergrass, sprangletop, ricefield bulrush, smallflower umbrella sedge, ducksalad, and redstem.

${ }^{\mathrm{b}} \mathrm{RSS}$, residual sums of squares.

${ }^{c}$ Significant $F$-values indicate differences between years. Model 1: $\mathrm{df}_{\text {num }}=1 ;$ Model 2: $\mathrm{df}_{\text {num }}=2$.

$*_{\mathrm{p}}<0.05$.

${ }_{* *} \mathrm{p}<0.01$.

$* * * \mathrm{p}<0.001$.

66 - Weed Science 65, January-February 2017 
Table 4. Root mean square error (RMSE), mean average error (MAE), and Akaike information criteria adjusted for small sample size (AICc) for Model 1 and 2 generated with relative cover data from rice grown at the CRES in Biggs, CA, in 2013 and 2014 , and Model 1 and 2 generated with data across four sites: Glenn County (GC), Butte County 1 (BC1), Butte County 2 (BC2) and Yuba County (YC) in 2013 and 2014.

\begin{tabular}{|c|c|c|c|c|c|c|c|c|}
\hline Sites & Year & Species group ${ }^{\mathrm{a}}$ & \multicolumn{3}{|c|}{ Model $1^{\mathrm{b}}$} & \multicolumn{3}{|c|}{ Model 2} \\
\hline \multirow[t]{6}{*}{ CRES } & \multirow[t]{4}{*}{2013} & Grasses & 0.13 & 0.10 & -8.7 & 0.13 & 0.10 & -5.7 \\
\hline & & Grasses + sedges & 0.06 & 0.05 & -21.5 & 0.06 & 0.05 & -18.2 \\
\hline & & Grasses + broadleaves & 0.19 & 0.16 & -1.3 & 0.19 & 0.13 & 1.3 \\
\hline & & Weeds combined & 0.19 & 0.15 & -1.9 & 0.18 & 0.13 & 0.7 \\
\hline & \multirow{2}{*}{2014} & Grasses + broadleaves & 0.11 & 0.08 & -12.8 & 0.09 & 0.07 & -11.0 \\
\hline & & Weeds combined & 0.13 & 0.10 & -8.7 & 0.11 & 0.08 & -7.6 \\
\hline \multirow[t]{4}{*}{ GC, BC1, BC2, YC } & \multirow[t]{4}{*}{2013} & Grasses & 0.16 & 0.14 & -54.0 & 0.09 & 0.06 & -128.6 \\
\hline & & Grasses + sedges & 0.14 & 0.11 & -73.1 & 0.09 & 0.06 & -134.0 \\
\hline & & Grasses + broadleaves & 0.13 & 0.09 & -81.3 & 0.09 & 0.06 & -131.2 \\
\hline & & Weeds combined & 0.10 & 0.07 & -113.0 & 0.10 & 0.07 & -121.0 \\
\hline
\end{tabular}

${ }^{a}$ See Table 3 for categories (grasses, grasses + sedges, grasses + broadleaves, and weeds combined).

${ }^{\mathrm{b}}$ Model 1: Equation 3. Model 2: Equation 4.

not significantly improve the model fit either year. Generally, RMSE and MAE did not vary significantly between Model 1 and Model 2 for the same independent variable. For the data generated at the GC, BC1, BC2, and YC sites combined, Model 2 was the better fit in 2013, and Model 1 the better fit in 2014. The differences between years can be explained by the large increase in relative damage coefficients $(q)$ with Model 2 in 2013. The fit of the model was also increased by shifting the predicted maximum YL $(m)$ down from the observed YL of 96\%. Although Model 2 fit better overall, the increase in $q$ values may lead to overestimation of $\mathrm{YL}$ at low weed relative cover.

Kropff et al. (1995) observed a better fit with Model 2 when evaluating the fit for barnyardgrass and heartshape false pickerelweed [Monochoria vaginalis (Burm.f.) C. Presl ex Kunth] in transplanted rice. However, they observed much lower yield losses than those observed in the current study, which explains why the addition of the upper asymptote increased model fit. In Colombia, where yield losses are high, there was no consistent improvement in model fit with the addition of an upper asymptote (Florez et al. 1999). The differences in model fits between Models 1 and 2 can be explained by the fact that in the California rice system, YL can reach $100 \%$ when weeds are not controlled (Table 5). High yield losses often occur in systems where the crop and the weed are equally good competitors for the same resources (Kropff and Spitters 1991).

The data from 2013 and 2014 could not be described with a single set of parameters over years (Table 3). Since this was true of both the models developed from the CRES data and the models developed from the combined sites (GC, BC1, BC2, and $\mathrm{YC}$ ) (unpublished data), the differences are likely due to environmental factors, including temperature. Average maximum temperature increased at all sites in 2014. Rice undergoes physiological changes at high temperatures including reductions in photosynthetic efficiency and in nutrient and water use efficiency (Krishnan et al. 2011), so increased temperatures may decrease the competitive ability of rice in comparison to some weed species. In Australia barnyardgrass showed increased competitive ability in comparison to rice at day/night temperatures above 27/21 C (Alberto et al. 1996). Research in the southern United States indicates that rice yields there are reduced at daytime maximum temperatures of more than $28 \mathrm{C}$ (Baker 2004; Baker and Allen 1993). Since all models showed smaller competition coefficients $(q)$ for all weed species in 2014 as compared with 2013 (Table 5), there may be an effect of increased daytime temperatures on weed physiology or growth as well. Watergrass and smallflower umbrella sedge, 
Table 5. Model parameters for Models 1 and 2, which were generated from relative cover data collected at the CRES, CA, in Biggs in 2013 and 2014, and from data collected over multiple sites: Glenn County (GC), Butte County 1 (BC1), Butte County 2 (BC2), and Yuba County (YC) in 2013 and 2014.

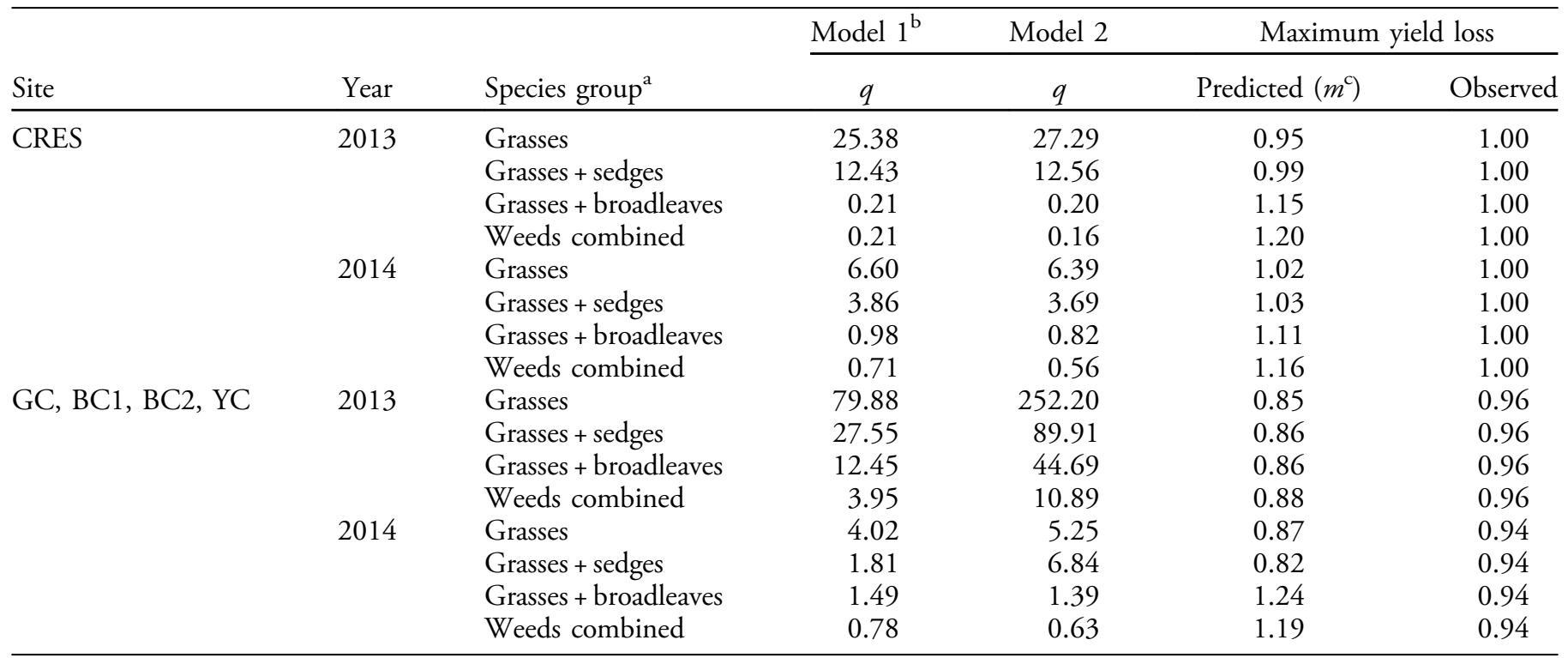

${ }^{\text {a }}$ See Table 3 for categories (grasses, grasses + sedges, grasses + broadleaves, and weeds combined).

${ }^{\mathrm{b}}$ Model 1: Equation 3. Model 2: Equation 4.

${ }^{\mathrm{c}}$ Predicted value $(m)$ generated from Model 2.

both $\mathrm{C}_{4}$ species, may have a competitive advantage under higher temperatures (Ehleringer et al. 1997). However, the decrease in the $q$ coefficient in comparison to 2013 indicates that another factor may have affected the relative competitive ability of the rice and weeds in 2014.

As timing of weed emergence relative to crop emergence is known to affect relative competitiveness, it is possible that emergence of some weeds was delayed in 2014 compared with 2013, although this still does not fully explain the decrease in the $q$-values in the second year, as higher temperatures should have increased soil temperature, thus decreasing the time to germination and emergence.

Model Fit by Species Group. Parameters ( $q$ and $m$ ) varied considerably between the different weed species groups and between sites (CRES vs. other sites combined) (Table 5). The variation in values between sites might be due to a number of factors, including differences in water management, variety, and soil type between sites. In general, the $q$ coefficient for grasses was the highest of any of the weed groups evaluated. Since $q$-values greater than 1 indicate the weed is more competitive than the crop, this clearly suggests that grasses are outcompeting rice in the mixed-weed species infestation. These results confirm earlier competition studies showing that barnyardgrass alone reduces yields in rice in the southern
United States by up to $79 \%$ when allowed to compete over the entire growing season (Smith 1968). Gibson et al. (2002) found that late watergrass can reduce yields up to $59 \%$ in California when left uncontrolled. Bearded sprangletop (Leptochloa fusca (L.) Kunth subsp. fascicularis (Lam.) N. Snow), another grass, reduced yields by up to $36 \%$ in season-long competition in Arkansas rice (Smith 1983). In comparison, the yield reduction from a broadleaf weed, ducksalad, was much less: up to $21 \%$ when left uncontrolled (Smith 1968). The $q$ coefficients for the grasses + sedges are all greater than 1 , although the coefficient is reduced in comparison to the coefficient from grasses alone. Adding broadleaves to the grasses further reduced the $q$ coefficients. When all weed species were combined, the $q$ coefficients were smallest $(<1)$ indicating that rice is more competitive than all of the weeds as a group when multiple weed species are present. This suggests that in a mixed-species infestation, grasses are the best competitor for resources such as light and soil nutrients, in comparison to both rice and other weed species. The ability of grasses to outcompete both broadleaves and sedges is supported by the fact that across all sites (GC, BC1, BC2, and $\mathrm{YC}$ ), there is a negative relationship between grasses and broadleaves as well as grasses and sedges (sedges vs. grasses: 2013, $y=-0.68 x+35.7, \quad \mathrm{R}^{2}=0.59 ; 2014, \quad y=-0.51 x+$ $30.5, R^{2}=0.33$; broadleaves vs. grasses: 2013 ,

68 - Weed Science 65, January-February 2017 
$y=-0.08 x+13.4, \quad \mathrm{R}^{2}=0.04 ; \quad 2014: \quad y=-1.02 x+$ $48.6, \mathrm{R}^{2}=0.35$ ). In general, yield losses are higher when weeds and crop have similar morphological and physiological characteristics (Radosevich et al. 1997), which in this system, would pertain to the grasses and rice.

Similar studies in rice have demonstrated the same competitive relationships between weed species and rice, with grasses as the most competitive and broadleaves as the least competitive. In Brazil a study using the relative cover of watergrass species as the predictive factor for yield loss had $q$ coefficients similar to those found in this study, ranging from 3.94 to 31.15 for Model 1 (Galon and Agostinetto 2009). Using relative leaf area as the predictive factor, Kropff et al. (1995) found that the $q$ coefficient for heartshape false pickerelweed, a broadleaf weed, using Model 1 was 0.73 . The $q$ coefficient for barnyardgrass was 1.05 for the same model. The Kropff et al. (1995) study was conducted in transplanted rice, which may explain the lower $q$ coefficients, since the rice was already large when weed emergence began, giving the rice a competitive advantage over the weeds.

In both 2013 and 2014, grasses were the better predictor of yield loss in comparison to sedges and broadleaves alone at the CRES (Figures 1 and 2). Sedges showed no trend either year, and broadleaves had a negative linear relationship with yield loss in this multispecies system (Figure 2). The same trend can be seen across the other sites; when the data were pooled, grasses were a good predictor of yield loss, sedges showed no relationship with yield loss, and broadleaves were negatively related to yield loss in the multispecies system (unpublished data). For the CRES data, when AICc values were compared, grasses and sedges combined were the best predictor in 2013 using Model 1, but grasses alone were the best predictor in 2014 using Model 1 (Table 4). In the other sites combined (GC, BC1, BC2, and GC), grasses and sedges combined were the best predictor in 2013 when using Model 2, but all species combined were the best fit for Model 1. Model 2 was the best fit overall for that season and data set (lowest AICc). In 2014 grasses and sedges combined were the best overall predictor, using Model 1. Overall, either grasses and sedges combined (3 site-years), or grasses alone (1 site-year) provided the best fit (lowest AICc). Model 1 was the better fit for 3 site-years, and Model 2 was the best fit for 1 site-year. This finding suggests that either grasses alone or grasses and sedges combined are the best predictor of yield loss in a multispecies infestation.
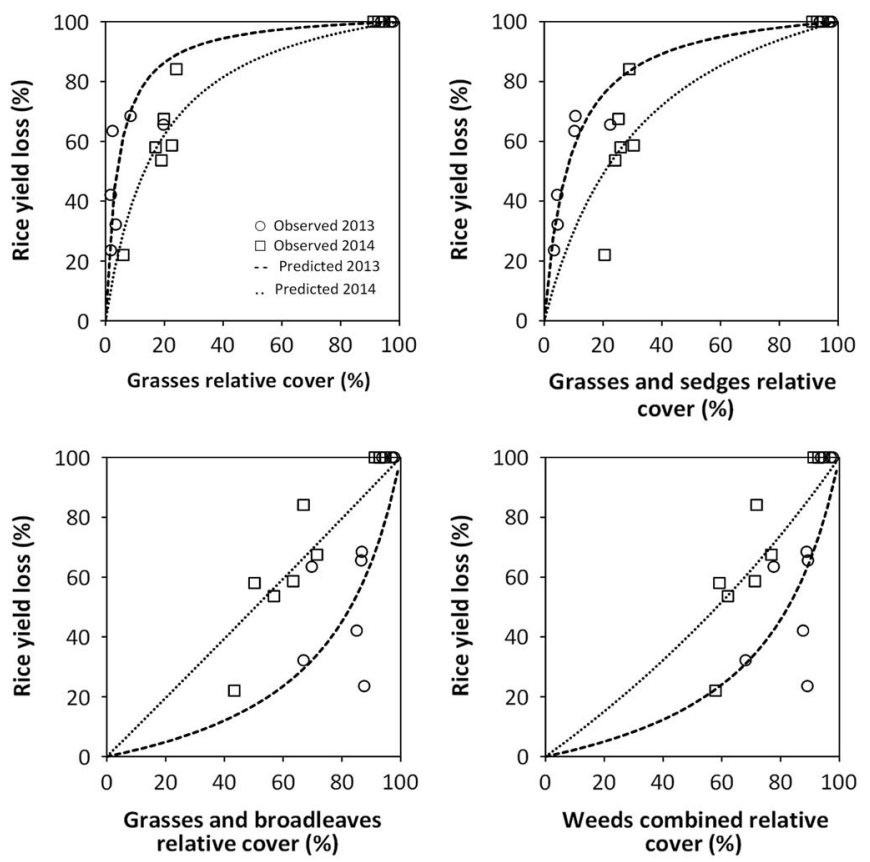

Figure 1. Predicted and observed rice yield loss values for Model $1, \mathrm{YL}=q \mathrm{RC} /[1+(q-1) \mathrm{RC}]$, generated at the CRES in Biggs, $\mathrm{CA}$, in 2013 and 2014. Independent variables are relative cover of grasses (watergrass and sprangletop), grasses and sedges (watergrass, sprangletop, ricefield bulrush, and smallflower umbrella sedge), grasses and broadleaves (watergrass, sprangletop, ducksalad, and redstem), and all weeds combined.
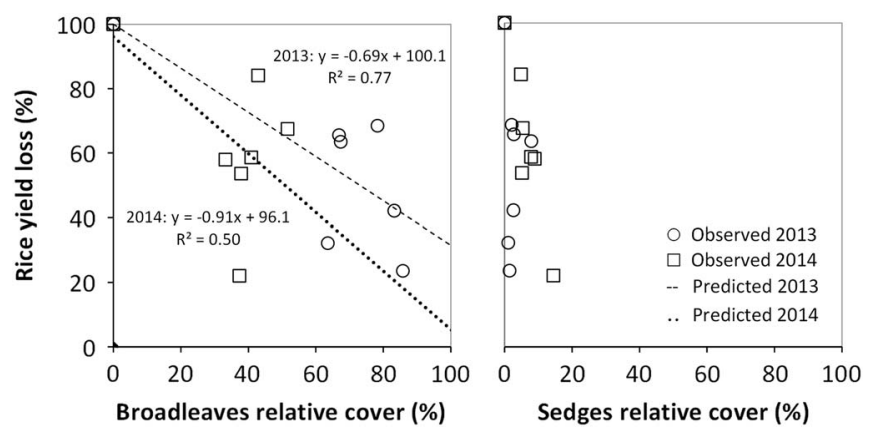

Figure 2. Relative cover of broadleaves and sedge vs. rice yield loss at the CRES in Biggs, CA, in 2013 and 2014. Data for broadleaf relative cover were fit using linear regression for 2013 and 2014 separately.

Model Validation. Models calibrated at the CRES site were fit to each validation site across the rice-growing region (Figure 3). There was variation among both sites and years in terms of goodness of model fit when comparing AICc (Table 6). In general, lowest MAE and RMSE corresponded with lowest AICc. Of the tested weed groups for the GC site, Model 1 best described the data (lowest AICc) in both 2013 and 2014. Grasses and sedges combined were the best predictor of yield loss in both 2013 and 2014. Overall, fit of the models at the GC 

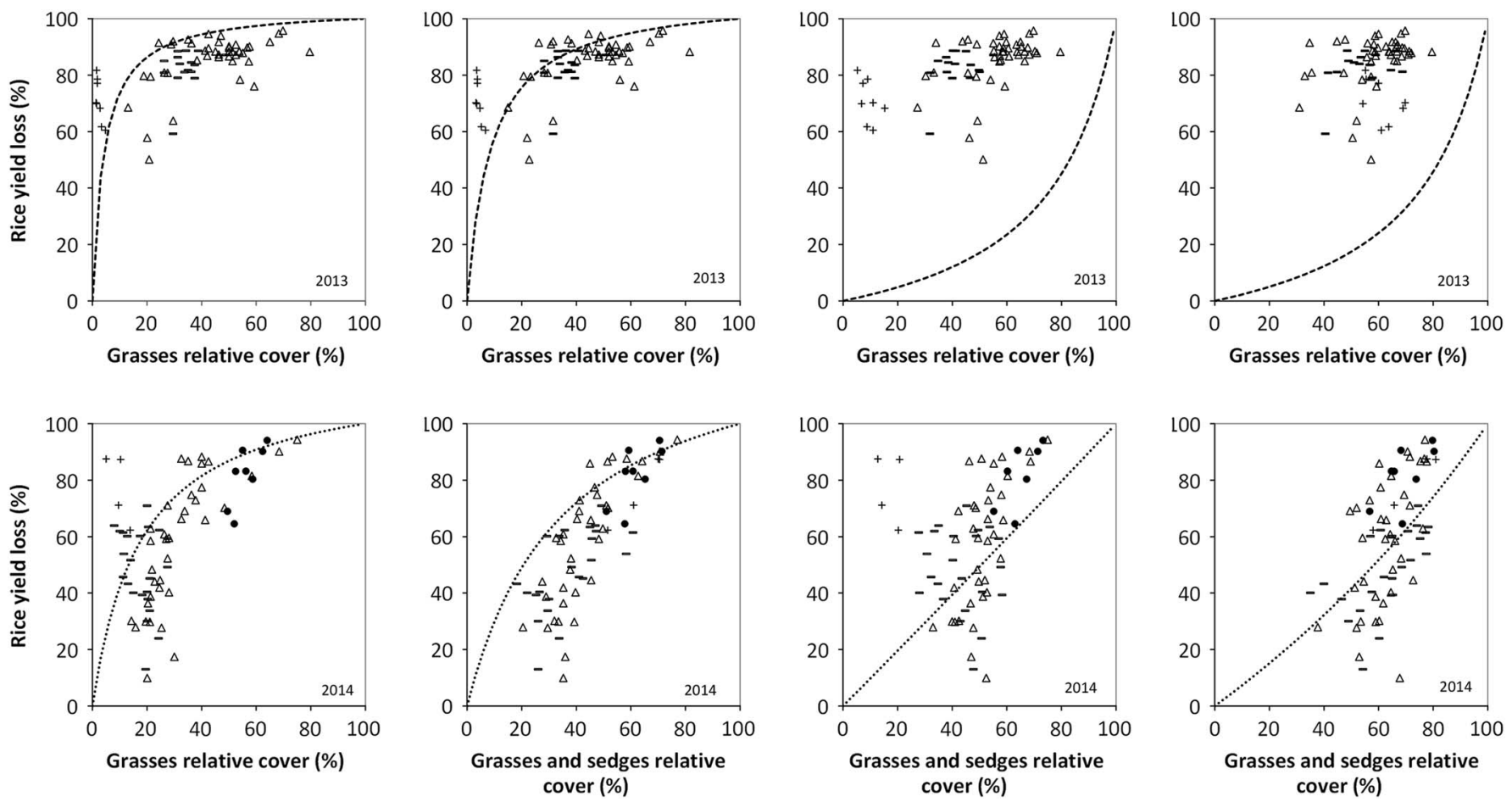

Figure 3. Predicted and observed rice yield loss values for Model $1, \mathrm{YL}=q \mathrm{RC} /[1+(q-1) \mathrm{RC}]$, across multiple sites in California in 2013 and 2014. Predicted values were generated using q-values from the model calibrated at the CRES in Biggs, CA. Independent variables are relative cover of grasses (watergrass and sprangletop), grasses and sedges (watergrass, sprangletop, ricefield bulrush, and smallflower umbrella sedge), grasses and broadleaves (watergrass, sprangletop, ducksalad and redstem), and all weeds combined across sites in California. Observed values: Glenn County $(+)$, Butte County $1(\Delta)$, Butte County $2(-)$ and Yuba County $(\bigcirc)$. Predicted values: $2013(--)$ and $2014(\cdots)$.

site was low. At the $\mathrm{BC} 1$ site, grasses and sedges combined were the best predictive factor, with Model 2 as the better fit. In 2014 Model 1 was the better fit, with combined weeds as the predictive factor. At the BC2 site in 2013, Model 1 using grasses and sedges combined was the best fit. In 2014 Model 1 was the better fit, with all weeds combined as the predictive factor. At the YC site, grasses alone provided the best fit, and Model 1 was a better fit than Model 2. To summarize, grasses and sedges combined were the best fit across all sites in 2013 using Model 1 (2 sites) and Model 2 (1 site). MAE in 2013 ranged from $6 \%$ at the $\mathrm{BC} 1$ site to $13 \%$ at the GC site. In 2014 the best predictive factor was grasses and sedges combined at two sites, and all weeds combined at two sites. Model 1 was the best fit across all sites. MAE ranged from $6 \%$ at the $\mathrm{YC}$ site to $17 \%$ at the $\mathrm{BC} 1$ site.

In spite of the fact that at some sites broadleaves and sedges were the dominant species in the mixedspecies infestations, RC of the dominant species alone was not useful in predicting $\mathrm{YL}$ in this natural community of mixed weed species (Figures 2 and 3 ). The best predictor at most of the validation sites $(5$ out of 7 site-years) was the combination of grasses and sedges. The same was true at the calibration sites (Table 2), where the combination of grasses and sedges was the best predictor in 3 out of 4 site-years. Since YL can reach $100 \%$ when weeds are uncontrolled in rice, there was no apparent benefit in general to the predictive value of using Model 2 over Model 1 (Kropff and Lotz 1993). Model 2 tends to overestimate YL, especially at low weed RC. While no single model could predict YL across all sites, grasses alone are the best independent variable in comparison to broadleaves or sedges alone (Figures 1 and 2). The addition of sedges or sedges plus broadleaves might increase the accuracy of the prediction, but the degree to which the model fit was improved depends on year and site. For the model validation, grass and sedge combined $\mathrm{RC}$ was the best predictor in 5 out of 7 site-years, and Model 1 was the best predictor in 6 out of 7 site-years.

This study illustrates that predictive models can be used as a tool to aid growers and advisers in the decision-making process to determine which weed species group to prioritize targeting in a mixedspecies weed community. In California rice, this is especially important, due to the large number of herbicide-resistant weed species, with growers having 
Table 6. Root mean square error (RMSE), mean average error (MAE), and Akaike information criteria adjusted for small sample size (AICc) using two yield prediction models and four species' groups as independent variables for models generated at the CRES in Biggs, CA, in 2013 and 2014 and validated across four sites in 2013 and 2014: Glenn County (GC), Butte County 1 (BC1), Butte County 2 (BC2), and Yuba County (YC).

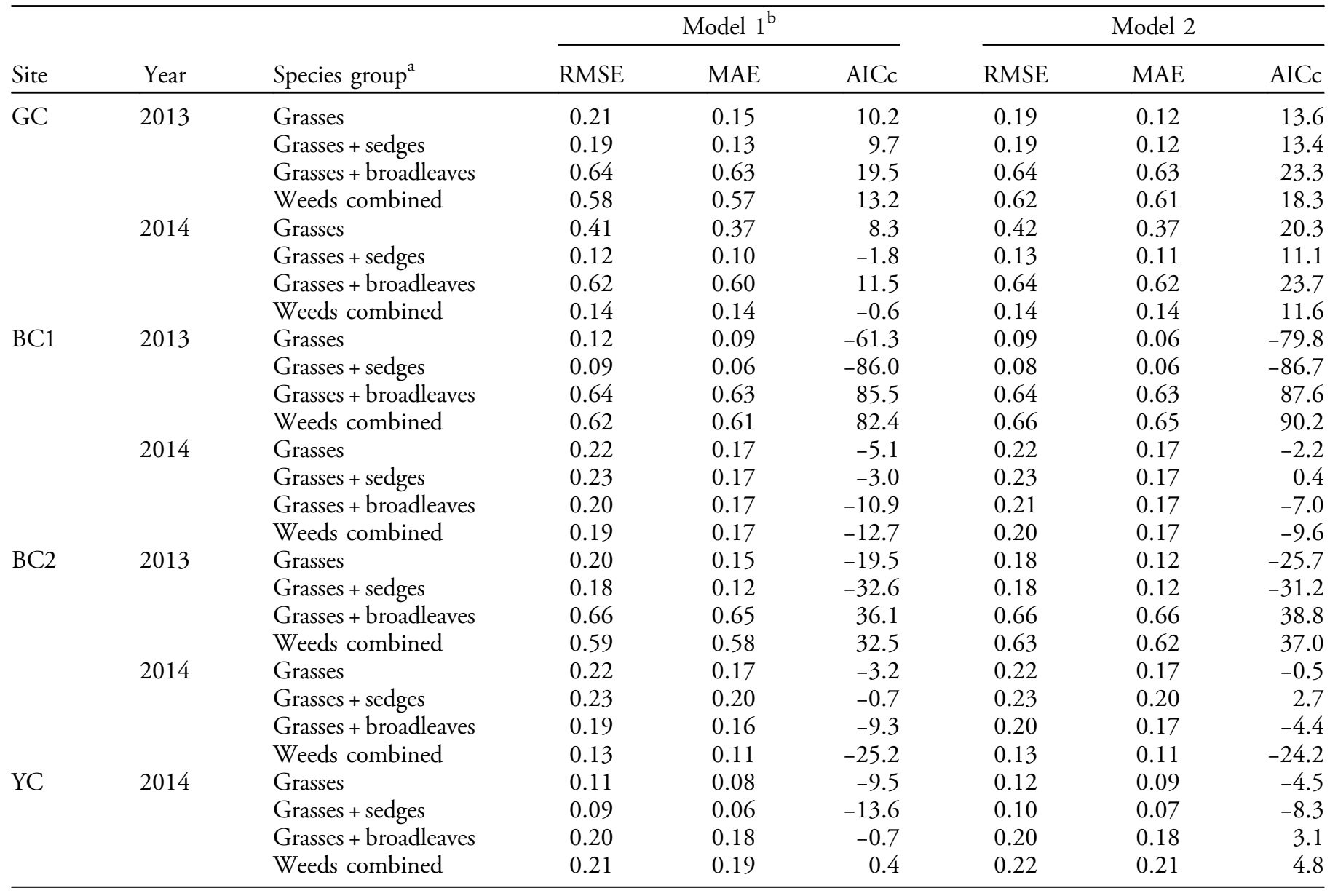

${ }^{a}$ See Table 3 for categories (grasses, grasses + sedges, grasses + broadleaves, and weeds combined).

${ }^{\mathrm{b}}$ Model 1: Equation 3. Model 2: Equation 4.

to choose which species to control over others. In order for this model to be more useful, it needs to be tested across a wide array of weed populations with varying degrees of relative cover in the field. Effects of rice cultivar and temperature may need to be incorporated into the model to improve accuracy.

\section{Acknowledgments}

The study was funded by the California Rice Research Board. The CRES and Kent McKenzie provided equipment and the experimental site. Cooperating growers who provided additional sites in Glenn and Yuba Counties were T. Rogers and the Inderbitzen Brothers, respectively.

\section{Literature Cited}

Alberto AMP, Ziska KH, Cervancia CR, Manalo PA (1996) The influence of increasing arbon dioxide and temperature on competitive interactions between a $\mathrm{C}_{3}$ crop, rice (Oryza sativa) and a $\mathrm{C}_{4}$ weed (Echinochloa glabrescens). Aust J Plant Physiol 23:795-802

Ali A, Streibig JC, Andreasen C (2013) Yield loss prediction models based on early estimation of weed pressure. Crop Prot 53:125-131

Baker JT (2004) Yield responses of southern US rice cultivars to $\mathrm{CO}_{2}$ and temperature. Agric For Meteorol 122:129-137

Baker JT, Allen LH Jr. (1993) Effects of $\mathrm{CO}_{2}$ and temperature on rice: a summary of five growing seasons. J Agric Meterol 48:575-582

Brim-DeForest WB, Al-Khatib K, Linquist BA, Fischer AJ (2017) Weed community dynamics and system productivity in alternative irrigation systems in California rice. Weed Sci. Forthcoming

Chai T, Draxler RR (2014) Root mean square error (RMSE) or mean absolute error (MAE)? Arguments against avoiding RMSE in the literature. Geosci Model Dev 7:1247-1250

Chow GC (1960) Tests of equality between sets of coefficients in two linear regressions. Econometrica 28:591-605

[CIMIS] California Irrigation Management Information System. (2016) California Department of Water Resources. http:// www.cimis.water.ca.gov. Accessed February 27, 2016 
Cousens RD (1985) A simple model relating yield loss to weed density. Ann Appl Biol 107:239-252

Ehleringer JR, Cerling TE, Helliker BR (1997) $\mathrm{C}_{4}$ photosynthesis, atmospheric $\mathrm{CO}_{2}$ and climate. Oecologia 112:285-299

Fischer AJ, Ateh CM, Bayer DE, Hill JE (2000a) Herbicideresistant Echinochloa oryzoides and E. phyllopogon in CA Oryza sativa fields. Weed Sci 48:225-230

Fischer AJ, Bayer DE, Carriere MD, Ateh CM, Yim K-O (2000b) Mechanisms of resistance to bispyribac-sodium in an Echinochloa phyllopogon accession. Pestic Biochem Physiol 68:156-165

Florez JA, Fischer AJ, Ramirez H, Duque MC (1999) Predicting rice yield losses caused by multispecies weed competition. Agron J 91:87-92

Galon L, Agostinetto D (2009) Comparison of empirical models for predicting yield loss of irrigated rice (Oryza sativa) mixed with Echinochloa spp. Crop Prot 28:825-830

Gibson KD, Fischer AJ, Foin TC, Hill JE (2002) Implications of delayed Echinochloa spp. germination and duration of competition for integrated weed management in waterseeded rice. Weed Res 42:351-358

Hamill AS, Marriage PB, Friesen GA (1977) A method for assessing herbicide performance in small plot experiments. Weed Sci 25:386-389

Heap I (2016) The International Survey of Herbicide Resistant Weeds. https://www.weedscience.org. Accessed March 30, 2016

Kniss AR, Vassios JD, Nissen SJ, Ritz C (2011) Nonlinear regression analysis of herbicide absorption studies. Weed Sci 59:601-610

Krishnan P, Ramakrishnan B, Raja Reddy K, Reddy VR (2011) High temperature effects on rice growth, yield, and grain quality. Adv Agron 111:87-206

Kropff MJ, Lotz LAP (1993) Empirical models for crop-weed competition. Pages 9-24 in Kropff MJ \& van Laar HH, eds, Modeling Crop-Weed Interactions. Wallingford, UK: CABI

Kropff MJ, Spitters CJT (1991) A simple model of crop loss by weed competition from early observations on relative leaf area of the weeds. Weed Res 31:97-105

Kropff MJ, Lotz LAP, Weaver SE, Bos HJ, Wallinga J, Migo T (1995) A two-parameter model for prediction of crop loss by weed competition from early observations of relative area of weeds. Ann Appl Biol 126:329-346

Kwon TJ, Young DL, Young FL, Boerboom CM (1995) PALWEED:WHEAT: a bioeconomic decision model for postemergence weed management in winter wheat (Triticum aestivum). Weed Sci 43:595-603

LaHue GT, Chaney RL, Adviento-Borbe MA, Linquist BA (2016) Alternate wetting and drying in high yielding directseeded rice systems accomplishes multiple environmental and agronomic objectives. Agric Ecosyst Environ 229:30-39

Lutman PJW, Risiott R, Ostermann HP (1996) Investigations into alternative methods to predict the competitive effects of weeds on crop yields. Weed Sci 44:290-297

Ngouajio M, Lemieux C, Leroux GD (1999a) Prediction of corn (Zea mays) yield loss from early observations of the relative leaf area and the relative leaf cover of weeds. Weed Sci 47: 297-304

Ngouajio M, Leroux GD, Lemieux C (1999b) A flexible sigmoidal model relating crop yield to weed relative leaf cover and its comparison with nested models. Weed Res 39:329-343
Ngouajio M, Leroux GD, Lemieux C (1999c) Influence of images recording height and crop growth stage on leaf cover estimates and their performance in yield prediction models. Crop Prot 18:501-508

[NRCS] Natural Resources Conservation Service, United States Department of Agriculture (2016) Web Soil Survey. http:// websoilsurvey.nrcs.usda.gov. Accessed February 1, 2016

Pappas-Fader T, Cook JF, Butler T, Lana PJ, Hare J (1993) Resistance of CA arrowhead and smallflower umbrella plant to sulfonylurea herbicides. Page 76 in Proceedings of the Western Weed Science Society. Newark, CA: Western Society of Weed Science

Radosevich S, Holt J, Ghersa C (1997) Physiological aspects of competition. Pages 217-301 in Weed Ecology: Implications for Vegetation Management. 2nd edn. New York: Wiley

Richardson JW, Outlaw JL (2010) Economic Contributions of the US Rice Industry to the US Economy. College Station, TX: Agricultural and Food Policy Center Research Report 10-3. $20 \mathrm{p}$

Smith RJ Jr (1968) Weed competition in rice. Weed Sci 16: 252-255

Smith RJ Jr (1983) Competition of bearded sprangletop (Leptochloa fascicularis) with rice (Oryza sativa). Weed Sci 31:120-123

Smith RJ Jr (1988) Weed thresholds in southern US rice, Oryza sativa. Weed Tech 2:232-241

Spiess AN, Neumeyer N (2010) An evaluation of R2 as an inadequate measure for nonlinear models in pharmacological and biochemical research: a Monte Carlo approach. BMC Pharmacol 10:6

Swinton SM, Buhler DD, Forcella F, Gunsolus JL, King RP (1994) Estimation of crop yield loss due to interference by multiple weed species. Weed Sci 42:103-109

Van Acker RC, Lutman PJW, Froud-Williams RJ (1997) Predicting yield loss due to interference from two weed species using early observations of relative weed leaf area. Weed Res 37:287-299

Wilkerson GG, Modena SA, Coble HD (1991) HERB: decision model for post emergence weed control in soybean. Agron J 83:413-417

Williams JF (2010) Rice Nutrient Management in California. Riverhead, CA: University of California, Agricultural and Natural Resources. $136 \mathrm{p}$

Yasuor H, TenBrook PL, Tjeerdem RS, Fischer AJ (2008) Responses to clomazone and 5-ketoclomazone by Echinochloa phyllopogon resistant to multiple herbicides in CA rice fields. Pest Manag Sci 64:1031-1039

Yun MS, Yogo Y, Yamasue Y, Fischer AJ (2005) Cytochrome P-450 monooxygenase activity in herbicide-resistant and -susceptible late watergrass (Echinochloa phyllopogon). Pestic Biochem Physiol 83:107-114

Zhang ZP (1996) Weed management in transplanted rice. Pages 77-86 in Auld BA \& Kim KU eds. Weed Management in Rice. Rome, Italy: Food and Agriculture Organization of the United Nations

Received May 16, 2016, and approved August 5, 2016.

Associate Editor for this paper: J. Anita Dille, Kansas State University. 